\title{
Water Consumption in Ningxia Reach of the Yellow River since Integrated Regulation
}

\author{
Shuangyan Jin ${ }^{1}$, Xinhui Jiang², Ping Zhang1 \\ ${ }^{1}$ Yellow River Institute of Hydrology and Water Resources, Zhengzhou, China \\ ${ }^{2}$ Hydrology Bureau of Yellow River Conservancy Commission, Zhengzhou, China \\ Email: 1178922805@qq.com
}

How to cite this paper: Jin, S.Y., Jiang, X.H. and Zhang, P. (2017) Water Consumption in Ningxia Reach of the Yellow River since Integrated Regulation. World Journal of Engineering and Technology, 5, 54-61.

https://doi.org/10.4236/wjet.2017.53B007

Received: May 12, 2017

Accepted: August 8, 2017

Published: August 11, 2017

\begin{abstract}
The annual allocation, inter-annual variation and relation of water diversion and recession are analyzed in Ningxia reach of the Yellow River main stream from 1999 to 2012. Water consumption in Ningxia reach was calculated by water diversion-recession method and water balance method. The average value of water diversion-recession method is 3.264 billion $\mathrm{m}^{3}$ and annual variation is relatively steady. The result of water balance method is 3.937 billion $\mathrm{m}^{3}$ and annual variation is obvious. It is suggested that strengthen verification of entrances and monitoring of water diversion and recession.
\end{abstract}

\section{Keywords}

Water Consumption, Water Diversion-Recession Method, Water Balance Method, Water Diversion Quantity, Water Recession Quantity, Ningxia Reach, Integrated Water Regulation

\section{Background and Data}

\subsection{Background}

The Yellow River water regulation implements double control principles, i.e. total water consumption and discharge of control section [1]. Water diversion of the Yellow River main stream in Ningxia reach is mainly from irrigation, industry and urban living water, and water recession mainly related to agricultural irrigation and process structure of industrial water. In recent years, the complexity of water diversion and recession was increased due to the development of agricultural irrigation rule, water-saving transformation, water recession reuse, and construction of industrial base in Yellow River irrigation district. Therefore, scale and proportion of water diversion-recession and water consumption in 
Ningxia reach since integrated regulation are needed to analyze for united management and optimal configuration of the Yellow River water resources.

\subsection{Basic Data}

Integrated water resources regulation of Yellow River began in March 1999 [2], so the year from 1999 to 2012 is selected as study period. Water diversion-recession data are from monthly report of water diversion project which have license issued by Yellow River Conservancy Commission. Hydrology data of different time scale in main stream and tributaries of Yellow River are from Yellow River basin hydrological almanac [3].

\section{Method}

\subsection{Method of Water Diversion and Recession}

For particular river section, water consumption is the difference of water diversion and water recession, based on the calculation of observed water diversion and water recession.

$$
W_{C}=W_{D}-W_{R}
$$

where: $W_{\mathrm{C}}$, water consumption; $W_{\mathrm{D}}$, water diversion; $W_{\mathrm{R}}$, water recession.

The accuracy of the method result depends on the accuracy of the data of water diversion and water recession.

\subsection{Method of Water Balance}

Water balance method is based on the observed data of hydrological station, and evaporation and leakage loss were deducted from the difference of upper and lower section discharge, according to the principle of water balance [4] [5]. The equation is as follows:

$$
W_{\mathrm{C}}=\left(W_{\mathrm{U}}+W_{\mathrm{S}}+W_{\mathrm{UC}}\right)-\left(W_{\mathrm{E}} \pm W_{\mathrm{L}}\right)-W_{\mathrm{L}}
$$

where: $W_{\mathrm{U}}$, upper reach inflow; $W_{\mathrm{L}}$, lower reach effluent; $W_{\mathrm{S}}$, controlled water quantity; $W_{\mathrm{UC}}$, uncontrolled water quantity; $W_{\mathrm{E}}$, water surface evaporation; $W_{\mathrm{L}}$, section channel leakage; $W_{\mathrm{C}}$, industrial and agricultural water consumption.

According to features of the Yellow River, the interval water consumption of industry and agriculture has its special definition. Water consumption of agricultural irrigation refers to the water which can't return to the Yellow River due to evaporation and leakage in irrigation process of farmland, grassland, forest and so on. Water consumption of industrial and urban domestic includes user consumption and drainage loss, i.e. the difference of water diversion and waste water into rivers.

Water surface evaporation was calculated by observation data of the representative rainfall and evaporation stations year by year. Evaporating observation data of different evaporating dish are modified according to the coefficient given by the second national comprehensive planning of water resources. Water surface area is multiplied by mean width of monthly water surface, according to the 
data in Yellow River basin hydrology almanac, and distance between upper and lower station. The equation is as follows:

$$
\mathrm{W}_{\mathrm{E}}=((E \times a)-P) \times \mathrm{A}
$$

where: $W_{\mathrm{E}}$, net evaporation, $10^{8} \mathrm{~m}^{3} ; E$, mean annual evaporation, $\mathrm{mm}$; a, conversion coefficient of different evaporating dish; $P$, average rainfall, $\mathrm{mm} ; A$, water surface area, $\mathrm{km}^{2}$.

\section{Analysis of Water Diversion and Water Recession}

\subsection{Entrance Number of Water Diversion-Recession}

There are fourteen water diversion entrances in Ningxia Hui Autonomous Region approved by Yellow River Conservancy Commission. Among them, eight for agriculture, three for industry, two for hydropower and one for resident life [6].

In order to reflect the real status of water diversion and recession, remote sensing images of thirty meters resolution in Google earth were applied, and 140 water entrances and the latitude and longitude were identified from Xiaheyan to Shizuishan.

\subsection{Analysis of Water Diversion}

The Ningxia reach is divided into four parts, i.e. upper Xiaheyan, Xiaheyan Qingtongxia, Qingtongxia-Shizuishan, and lower Shizuishan. Water diversion of Weining Irrigation Area (WNIA) is the water diversion in Meiliqu and Xiaheyan Qingtongxia not include Dongganqu. Water diversion of Qingtongxia Irrigation Area (QTXIA) is the water diversion from Qingtongxia Shizuishan, Dongganqu and lower Shizuishan.

Water diversion in WNIA and QTXIA are mainly occurred in April to August and November, which just related to irrigation season [7]; nearly no water diversion in the other four months from December to March.

The annual water diversion in WNIA is 1.73 billion $\mathrm{m}^{3}$, which showed slow increasing trend. Among them, it is 1.723 billion $\mathrm{m}^{3}$ in Xiaheyan Qingtongxia. The lowest is 1.089 billion $\mathrm{m}^{3}$ occurred in the year 2003, and the highest is 2.044 billion $\mathrm{m}^{3}$ occurred in the year 2008 .

The annual water diversion in QTXIA is 5.08 billion $\mathrm{m}^{3}$, which showed slow decreasing trend. Among them, it is 4.467 billion $\mathrm{m}^{3}$ in Qingtongxia Shizuishan. The same as WNIA, the lowest is 1.089 billion $\mathrm{m}^{3}$ and also occurred in the year 2003, the reason is runoff in the main stream of Yellow River is low; the highest is 6896 billion $\mathrm{m}^{3}$ occurred in the year 1999 .

\subsection{Analysis of Water Recession}

Water recession in Ningxia reach is as follows: no water recession in Meiliqu upper Xiaheyan, water recession in Xiaheyan Qingtongxia is the same of WNIA and in Qingtongxia Shizuishan is the same of QTXIA, and no water recession lower Shizuishan. 
Water recession in WNIA and QTXIA is mainly occurred in May to August and November, which related to water diversion in irrigation area. Unlike variety of annual water diversion, water recession occurred in the whole year.

The average annual water recession in WNIA is 0.79 billion $\mathrm{m}^{3}$, which showed obvious yearly change. The lowest is 0.627 billion $\mathrm{m}^{3}$ occurred in the year 2009, and the highest is 1.108 billion $\mathrm{m}^{3}$ occurred in the year 2007 .

The average annual water recession in QTXIA is 2.752 billion $\mathrm{m}^{3}$, which showed slow decreasing trend. The lowest is 1.923 billion $\mathrm{m}^{3}$ occurred in the year 2003, and the highest is 4.053 billion $\mathrm{m}^{3}$ occurred in the year 1999 .

\subsection{Relationship of Water Diversion and Water Recession}

The average ratio of water recession and water diversion in WNIA is 0.46 , the maximum is 0.64 and the minimum is 0.35 , shown in Figure 1. There is no obvious relationship between water recession and diversion, shown in Figure 2 .

The average ratio of water recession and water diversion in QTXIA is 0.54 , the maximum is 0.63 and the minimum is 0.46 , shown in Figure 3. The relationship between water recession and diversion is very well-larger water diversion larger water recession, shown in Figure 4.

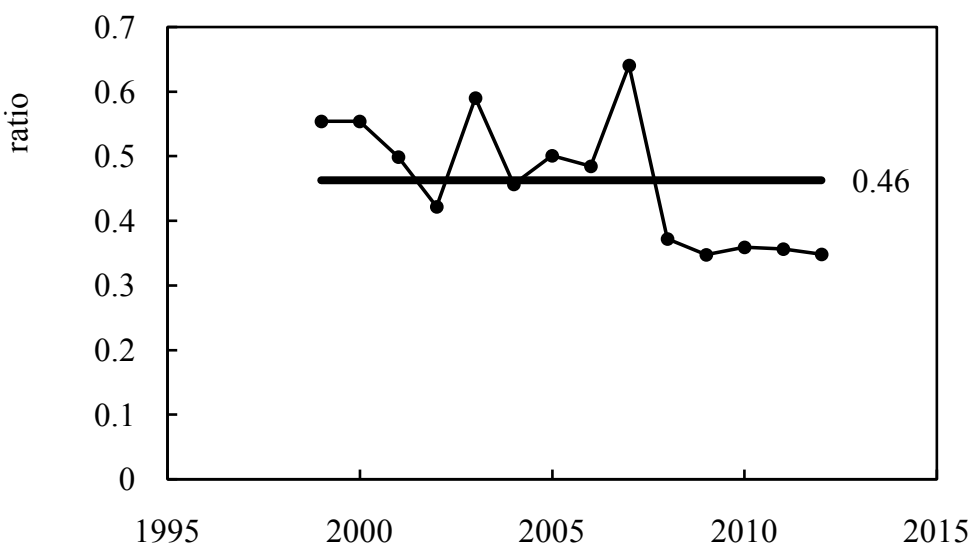

Figure 1. Ratio of water recession-diversion in WNIA.

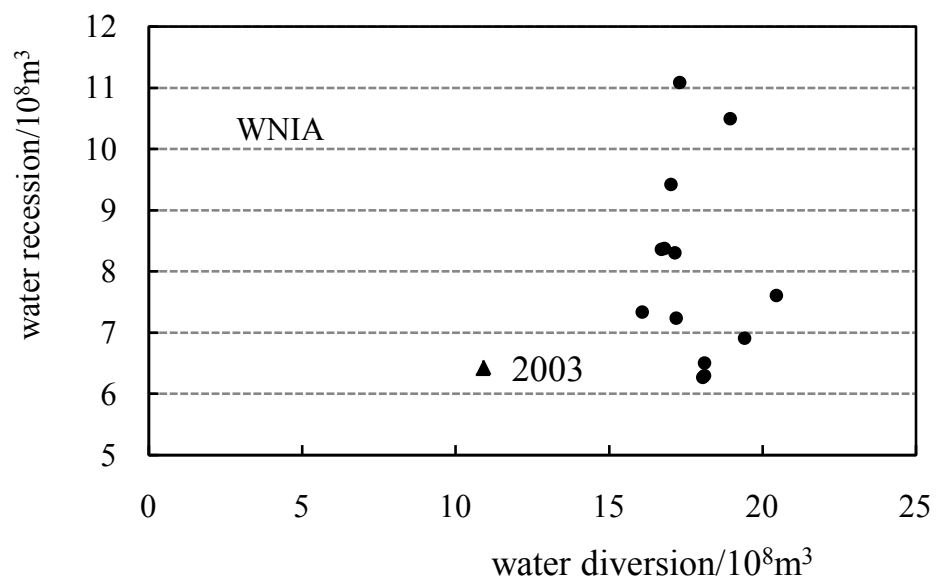

Figure 2. Relation of water diversion-recession. 


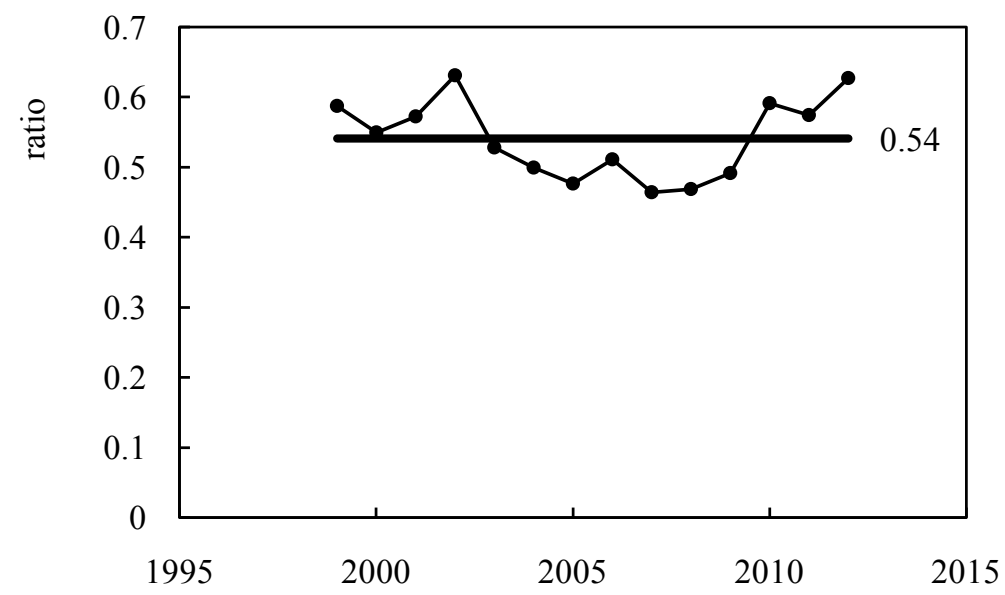

Figure 3. Ratio of water recession-diversion in QTXIA.

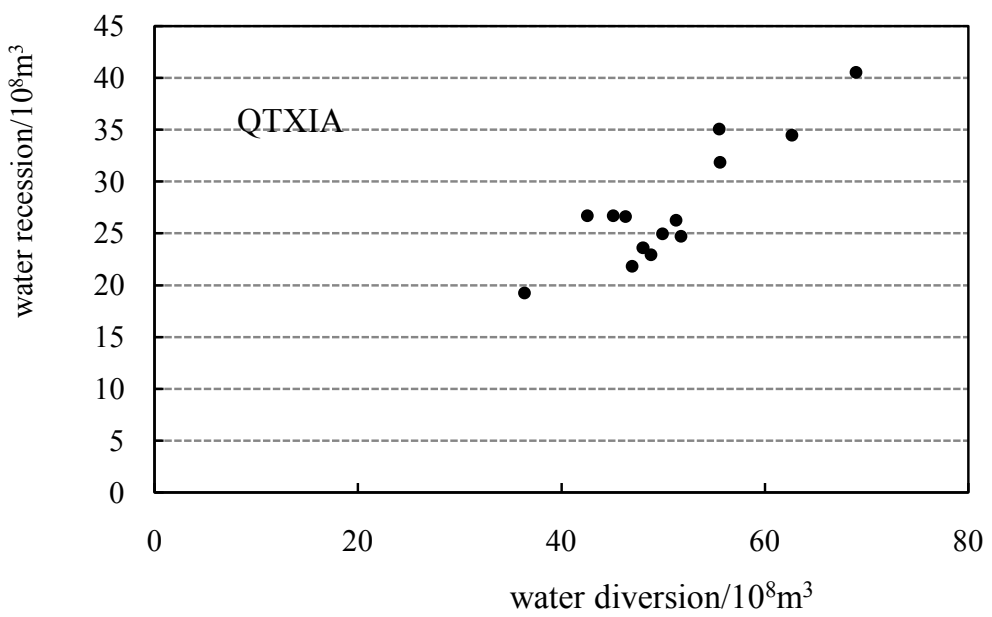

Figure 4. Relation of water diversion-recession.

\section{Analysis of Water Consumption}

\subsection{Results of Water Diversion-Recession Method}

Water diversion-recession in Ningxia irrigation area controlled better. Seventeen monitoring sites of water diversion and pumping diversion control more than $98 \%$ of the total irrigation area water diversion amount. Through various means such as measure, survey, investigation and so on, water recession was controlled over $90 \%$ of the whole irrigation area [8] [9].

(1) Water diversion. There is one water diversion entrance locates upper Xiaheyan, six locate in Xiaheyan Qingtongxia, two locate between Qingtongxia and Shizuishan, three locate lower Shizuishan. The sum of each river channel is the total water diversion.

(2) Water recession. The total water recession includes WNIA, QTXIA and Qingshui River's water recession [10]. WNIA includes first drainage ditch in Hebei irrigation area, ninth drainage ditch, Beihezigou, Nanhezigou and Hongliugou etc. in Henan irrigation area. QTXIA includes five drainage ditches in Hedong irrigation area, thirteen drainage ditches in Hexi irrigation area, and a 
little recession in Taole irrigation area.

(3) Water consumption. The average water consumption in Ningxia reach is 3.264 billion $\mathrm{m}^{3}$. The lowest is 2.161 billion $\mathrm{m}^{3}$ occurred in the year 2003 , and the highest is 3.875 billion $\mathrm{m}^{3}$ occurred in the year 2008. Except the year 2003 and 2012, the other annual water consumption is between $3.0-3.875$ billion $\mathrm{m}^{3}$, shown in Table 1.

\subsection{Results of Water Balance}

1) Controlled water quantity. There are three tributaries of the Yellow River in Ningxia reach, Qingshui River, Hongliugou and Kushui River. Hydrology station is Quanyanshan, mingshazhou and Guojiaqiao respectively. The observed hydrology data is from 1999 to 2012.

2) Uncontrolled water quantity. Uncontrolled water quantity in Xiaheyan Qingtongxia was calculated by mean runoff coefficient of Qingshui River and Hongliugou multiply uncontrolled catchment area, and it was calculated by mean runoff coefficient of Kushui River multiply uncontrolled catchment area in Qingtongxia Shizuishan.

3) Water surface evaporation. It is calculated by observed data of the representative rainfall station and evaporation station year by year.

4) Water consumption. The average water consumption in Ningxia reach is 3.937 billion $\mathrm{m}^{3}$. The lowest is 3.201 billion $\mathrm{m}^{3}$ occurred in the year 2003, and the highest is 5.123 billion $\mathrm{m}^{3}$ occurred in the year 2005, shown in Table 2.

Table 1. Water consumption by water diversion-recession method in 1999-2012 Unit: $10^{8}$ $\mathrm{m}^{3}$.

\begin{tabular}{cccccc}
\hline Year & $\begin{array}{c}\text { Total Ningxia } \\
\text { section }\end{array}$ & $\begin{array}{c}\text { Boundary } \\
\sim \text { Xiaheyan }\end{array}$ & $\begin{array}{c}\text { Xiaheyan } \\
\sim \text { Qingtongxia }\end{array}$ & $\begin{array}{c}\text { Qingtongxia } \\
\sim \text { Shizuishan }\end{array}$ & $\begin{array}{c}\text { Shizuishan } \\
\sim \text { Boundary }\end{array}$ \\
\hline 1999 & 36.868 & 6.021 & 7.579 & 21.881 & 1.387 \\
2000 & 35.783 & 5.239 & 7.130 & 21.850 & 1.563 \\
2001 & 32.173 & 4.702 & 8.259 & 17.102 & 2.110 \\
2002 & 30.411 & 4.585 & 9.923 & 14.339 & 1.564 \\
2003 & 21.613 & 2.406 & 5.103 & 12.030 & 2.075 \\
2004 & 33.727 & 4.381 & 8.662 & 18.385 & 2.298 \\
2005 & 35.416 & 4.121 & 9.013 & 20.151 & 2.132 \\
2006 & 35.258 & 4.749 & 9.035 & 18.241 & 3.234 \\
2007 & 31.354 & 4.521 & 5.947 & 19.570 & 1.316 \\
2008 & 38.748 & 4.799 & 12.798 & 20.058 & 1.092 \\
2009 & 36.195 & 4.637 & 11.678 & 18.324 & 1.556 \\
2010 & 30.019 & 4.489 & 12.278 & 12.718 & 0.534 \\
2011 & 31.727 & 5.636 & 11.734 & 13.815 & 0.541 \\
2012 & 27.657 & 4.677 & 11.371 & 11.175 & 0.433 \\
Average & 32.639 & 4.640 & 9.322 & 17.117 & 1.560 \\
\hline
\end{tabular}


Table 2. Water consumption by water balance method in 1999 2012 in Ningxia Reach Unit: $10^{8} \mathrm{~m}^{3}$

\begin{tabular}{|c|c|c|c|c|c|c|c|c|}
\hline \multirow{2}{*}{ Year } & \multirow{2}{*}{$\begin{array}{c}\text { Observed } \\
\text { runoff in } \\
\text { Xiaheyan \& }\end{array}$} & \multicolumn{4}{|c|}{ Section } & \multirow{2}{*}{$\begin{array}{c}\text { Xiaheyan } \\
+ \\
\text { Section }\end{array}$} & \multirow{2}{*}{$\begin{array}{l}\text { Observed } \\
\text { runoff in } \\
\text { Shizuishan }\end{array}$} & \multirow{2}{*}{$\begin{array}{c}\text { Calculated } \\
W_{\mathrm{C}}\end{array}$} \\
\hline & & Controlled & Uncontrolled & Evaporation & Sum & & & \\
\hline 1999 & 268.8 & 2.553 & 1.093 & 0.867 & 2.779 & 271.6 & 227.6 & 43.98 \\
\hline 2000 & 235.3 & 1.877 & 0.971 & 0.637 & 2.211 & 237.5 & 204.7 & 32.81 \\
\hline 2001 & 216.0 & 2.166 & 1.023 & 0.735 & 2.454 & 218.5 & 181.1 & 37.35 \\
\hline 2002 & 218.0 & 2.099 & 1.011 & 0.712 & 2.398 & 220.4 & 183.9 & 36.50 \\
\hline 2003 & 202.4 & 1.751 & 0.949 & 0.594 & 2.106 & 204.5 & 172.5 & 32.01 \\
\hline 2004 & 220.0 & 2.546 & 1.092 & 0.864 & 2.774 & 222.8 & 178.7 & 44.07 \\
\hline 2005 & 271.3 & 2.926 & 1.160 & 0.993 & 3.093 & 274.4 & 223.2 & 51.23 \\
\hline 2006 & 278.1 & 4.041 & 1.506 & 1.120 & 4.427 & 282.5 & 233.6 & 48.93 \\
\hline 2007 & 283.3 & 4.058 & 1.254 & 1.140 & 4.172 & 287.5 & 244.6 & 42.87 \\
\hline 2008 & 263.1 & 3.138 & 1.123 & 1.060 & 2.701 & 265.8 & 224.8 & 41.00 \\
\hline 2009 & 283.7 & 3.238 & 1.300 & 1.150 & 3.388 & 287.1 & 241.6 & 45.49 \\
\hline 2010 & 295.0 & 3.389 & 1.240 & 1.190 & 3.439 & 298.4 & 262.5 & 35.94 \\
\hline 2011 & 277.4 & 3.062 & 1.108 & 1.120 & 3.050 & 280.5 & 241.2 & 39.25 \\
\hline 2012 & 374.4 & 2.231 & 1.082 & 1.080 & 2.233 & 376.7 & 356.9 & 19.76 \\
\hline Mean & 263.3 & 2.791 & 1.137 & 0.947 & 2.945 & 266.3 & 226.9 & 39.37 \\
\hline
\end{tabular}

\subsection{Comparison of the Two Methods}

Through comparison of water consumption calculation results by the two methods, we can see water consumption calculated by water balance method is large than that calculated by water diversion-recession method. The mean water consumption calculated by water balance method is 3.937 billion $\mathrm{m}^{3}$, while by water diversion-recession method is 3.264 billion $\mathrm{m}^{3}$, and the difference is 0.673 billion $\mathrm{m}^{3}$.

\section{Conclusions and Suggestions}

1) Water diversion in Ningxia reach is mainly occurred in April to August and November, and the mean water diversion in 1999-2012 is 6.81 billion $\mathrm{m}^{3}$. The mean value in WNIA is 1.73 billion $\mathrm{m}^{3}$, which showed slowly increasing trend; the mean value in QTXIA is 5.08 billion $\mathrm{m}^{3}$, which showed slowly decreasing trend.

2) Water recession in Ningxia reach is mainly occurred in May to August and November, and mean water diversion in 1999-2012 is 3.542 billion $\mathrm{m}^{3}$. The mean value in WNIA is 0.79 billion $\mathrm{m}^{3}$, which showed obvious yearly change; the mean value in QTXIA is 2.752 billion $\mathrm{m}^{3}$, which showed slowly decreasing trend.

3) The average ratio of water recession-diversion in WNIA is 0.46 , and there is no obvious relationship between water recession-diversion. The mean ratio is 
0.54 in QTXIA, and relation between water recession-diversion is very well, larger water diversion larger water recession.

4) The average water consumption by water diversion-recession method from 1999 to 2012 in Ningxia reach is 3.264 billion $\mathrm{m}^{3}$. The inter-annual change is relatively steady. Except the year 2003 and 2012, the other annual water consumption is between $3.0-3.875$ billion $\mathrm{m}^{3}$.

5) The average water consumption by water balance method from 1999 to 2012 in Ningxia reach is 3.937 billion $\mathrm{m}^{3}$. The inter-annual variation is obvious.

6) It is suggested that strengthen verification of entrances and monitoring of water diversion and recession, in order to further analyze the reason of water consumption difference calculated by two different methods.

\section{Foundation}

National Science and Technology Pillar Program (2012BAB02B04), Central Water Resources Project in 2013.

\section{References}

[1] Ke, S.J. and Zhou, K.J. (2007) Study on the Mechanism of Integrated Water Resources Management in the Yellow River Basin. Yellow River, 29, 5-7. (In Chinese)

[2] Li, G.Y. (2005) Keep Healthy Life of the Yellow River. Yellow River Water Conservancy Press, Zhengzhou. (In Chinese)

[3] Hydrology Bureau of Yellow River Conservancy Commission, Yellow River Basin Hydrology Almanac, 1999-2012. (In Chinese)

[4] Zhang, X.C., Wang, L. and Si, F.L. (2001) Analysis of Water Consumption Prediction of the Yellow River runoff. Water Resources and Hydropower Engineering, 32, 8-11. (In Chinese)

[5] Zhang, X.C., Liu, C.M. and Li, D.Y. (2005) Analysis on Yellow River Surface Runoff Consumption. Acta Geographica Sinica, 60, 79-86. (In Chinese)

[6] The Upper and Middle Reaches of the Yellow River Administration Bureau, Data Compilation of Water Permit Regulatory in the Yellow River Upper and Middle Reaches. Oct. 2011. (In Chinese)

[7] Zhang, X.Y., Bao, S.P. and Feng, P.X. (2007) Analysis on the Dynamic Rule and Impact of Groundwater in Weining Irrigation District. Journal of Water Resources and Water Engineering, 18, 103-105. (In Chinese)

[8] (1999) Research on Water Diversion from the Yellow River Water in Hetao Irrigation Area of Ningxia. China Rural Water and Hydropower, No. 11, 4-7. (In Chinese)

[9] The Ningxia Hui Autonomous Region Water Conservancy Bureau, Survey Report on the Water Resource in the Ningxia Hui Autonomous Region/County. May 2010. (In Chinese)

[10] Ningxia Hydrology and Water Resources Survey Bureau. Ningxia Water Resources Bulletin, Yinchuan: Ningxia Hui Autonomous Region Water Conservancy Bureau, 2011. (In Chinese) 
Submit or recommend next manuscript to SCIRP and we will provide best service for you:

Accepting pre-submission inquiries through Email, Facebook, LinkedIn, Twitter, etc. A wide selection of journals (inclusive of 9 subjects, more than 200 journals)

Providing 24-hour high-quality service

User-friendly online submission system

Fair and swift peer-review system

Efficient typesetting and proofreading procedure

Display of the result of downloads and visits, as well as the number of cited articles Maximum dissemination of your research work

Submit your manuscript at: http://papersubmission.scirp.org/

Or contact wjet@scirp.org 